\title{
Influence of cutting parameters on surface quality when machining a CoCrWNi alloy
}

\author{
Manuela-Roxana Dijmărescu ${ }^{1, *}$, Ioan-Cristian Tarbă ${ }^{1}$, Maria-Cristina Dijmărescu ${ }^{2}$ and \\ Vlad Gheorghiță ${ }^{1}$ \\ ${ }^{1}$ University POLITEHNICA of Bucharest, Department of Manufacturing Engineering, Splaiul \\ Independentei, no. 313, 060042, Bucharest, Romania \\ ${ }^{2}$ University POLITEHNICA of Bucharest, Department of Materials Technology and Welding, Splaiul \\ Independentei, no. 313, 060042, Bucharest, Romania
}

\begin{abstract}
Due to their excellent biocompatibility and mechanical properties, the use of $\mathrm{Co}-\mathrm{Cr}$ based alloys in medical applications has increased substantially. An important characteristic of the medical implants is their surface quality, this being a significant constraint when machining this kind of products. The aim of this paper is to present a research conducted in order to determine and expose the influence of turning cutting parameters on the surface roughness of a CoCrWNi alloy.
\end{abstract}

\section{Introduction}

The synthetic materials used to manufacture parts which can augment or replace the function of a living system component are called biomaterials. These synthetic materials can be metallic, ceramic, polymeric or composite $[1,2]$. The requirements imposed to a certain material in order to be used for manufacturing human body implants are related to its corrosion and fatigue resistance, biocompatibility, osseointegration, modulus of elasticity, machinability and availability [1,3]. The metals which comply with these requirements are stainless steels, titanium and titanium alloys, cobalt-chromium alloys, magnesium alloys, tantalum and nickel-titanium alloys - shape memory alloys $[1,3,4]$.

The osseointegration property of the implants is very closely related to their surface quality [5], obtaining a good surface quality being very important for the implant functionality and for its integration with the body tissue $[4,5,6]$. When talking about machined surfaces, the factors that influence their quality the most are: the material characteristics, the tool geometry, the cutting parameters and the lubrication fluid [7,8].

Lately, Co-Cr based alloys are gaining popularity in medical and aerospace applications, mostly because of their good mechanical properties - high resistance to wear, good corrosion resistance, high hardness, heat resistance - and their biocompatibility [4, 7]. The Co-Cr based alloys recommended to be used in medical applications are: CoCrMo alloy, CoCrWNi alloy, CoNiCrMo alloy and CoNiCrMoWFe alloy $[1,8]$. Machining these alloys is still facing challenges and difficulties due to their high strength, wear resistance and toughness $[4,6,8]$.

\footnotetext{
*Corresponding author: manuela.dijmarescu@imst.pub.ro
} 


\section{Objective and research program}

The main objective of the research presented in this paper is to study the influence of certain cutting regime parameters - depth of cut, feed rate, and cutting speed - upon the surface quality of a CoCrWNi alloy when dry turning using TiAlN PVD coated inserts.

The research program has been structured as follows: determining some effective defining characteristics of the CoCrWNi alloy (chemical composition, hardness), defining the cutting regime parameters, preparation of the material samples, samples processing (dry longitudinal turning), roughness measurement ( $\mathrm{Ra}$ parameter), data registration and processing using a special software, drawing the influence charts of each cutting parameter upon surface roughness and presenting conclusions.

\section{Physical experiment details}

In this section, general information regarding the effective characteristics of the material and the processing experiment in terms of input, technological system elements, process and registration of the experimental data will be presented.

\subsection{Material characteristics}

Because the chemical composition and the mechanical properties of the blank material especially its hardness - have a major influence in the cutting process, it was decided to determine the effective values of these properties in order to define the cutting regime parameters within the experimental program. The CoCrWNi alloy standard required and the effective chemical composition are shown in Table 1 and its effective hardness values are shown in Table 2.

Table 1. Chemical composition of CoCrWNi alloy $[1,9]$.

\begin{tabular}{|c|c|c|}
\hline $\begin{array}{c}\text { Chemical } \\
\text { element }\end{array}$ & $\begin{array}{c}\text { Standard } \\
\text { requirements (\%) }\end{array}$ & $\begin{array}{c}\text { Effective } \\
\text { values (\%) }\end{array}$ \\
\hline $\mathrm{Cr}$ & $19-21$ & 19.68 \\
\hline $\mathrm{Ni}$ & $9-11$ & 10.13 \\
\hline $\mathrm{Fe}$ & max. 3 & 2.11 \\
\hline $\mathrm{C}$ & $0.05-0.15$ & 0.09 \\
\hline $\mathrm{Si}$ & max. 1 & 0.72 \\
\hline $\mathrm{Mn}$ & max. 2 & 1.04 \\
\hline $\mathrm{W}$ & $14-16$ & 15.1 \\
\hline $\mathrm{P}$ & max. 0.04 & 0.015 \\
\hline $\mathrm{S}$ & max. 0.03 & 0.022 \\
\hline $\mathrm{Co}$ & Balanced & Balanced \\
\hline
\end{tabular}

Table 2. Effective hardness of CoCrWNi samples.

\begin{tabular}{|c|c|}
\hline Variation range (HRC) & Average value (HRC) \\
\hline $35-37.7$ & 36.35 \\
\hline
\end{tabular}




\subsection{Experiment setup}

The experimental conditions are as follows:

- Machine tool: SN 320 precision lathe.

- Cutting tool: PCLNR 2525M-12X-JHP lever lock tool (see Figure 1.a) with rhombic CNMG 120404-VL TiAlN PVD coated inserts (see Figure 1.b).

- Processing type: dry longitudinal turning.

- Workpiece(s): CoCrWNi samples.

- Cutting parameters: depth of cut, $a_{p}$, feed rate, f, and cutting speed, $v_{c}$ (see Table 3).

- Roughness tester: Insize ISR-C002 with special software for data registration and processing.



$\mathrm{B}=25 \mathrm{~mm}|\mathrm{H}=25 \mathrm{~mm}| \mathrm{HF}=25 \mathrm{~mm}$ $\mathrm{LF}=150 \mathrm{~mm}|\mathrm{LH}=33 \mathrm{~mm}| \mathrm{WF}=32 \mathrm{~mm}$

a)

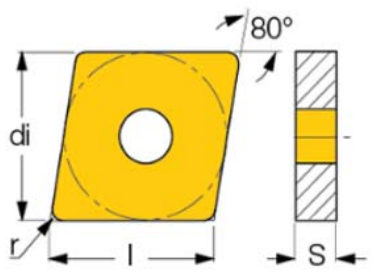

$\mathrm{r}=0,4 \mathrm{~mm} \quad \mathrm{di}=12,7 \mathrm{~mm}$ $1=12,9 \mathrm{~mm} \mid \mathrm{S}=4,76 \mathrm{~mm}$

b)

Fig. 1. Lever lock tool (a) and cutting insert (b) geometrical characteristics [10, 11].

Table 3. Ranges of the cutting regime parameters.

\begin{tabular}{|c|c|c|}
\hline Depth of cut, $\mathrm{a}_{\mathrm{p}}(\mathrm{mm})$ & Feed rate, $\mathrm{f}(\mathrm{mm} / \mathrm{rev})$ & Cutting speed, $\mathrm{v}_{\mathrm{c}}(\mathrm{m} / \mathrm{min})$ \\
\hline $0.25-0.50$ & $0.03-0.07$ & $20-32$ \\
\hline
\end{tabular}

\subsection{Experimental data}

Under the presented experimental conditions, thirteen processing experiments were conducted $(\mathrm{E} 1 \div \mathrm{E} 13)$. After processing each sample, the Ra roughness parameter for the machined surface was measured. The parameters used for the measurements are presented in Table 4.

Table 4. Parameters used for roughness measurements.

\begin{tabular}{|c|c|c|c|}
\hline $\begin{array}{c}\text { Cut-off value } \\
\lambda_{\mathrm{c}}(\mathrm{mm})\end{array}$ & $\begin{array}{c}\text { Evaluation length } \\
\mathrm{L}_{\mathrm{t}}(\mathrm{mm})\end{array}$ & Range $(\mu \mathrm{m})$ & Filter \\
\hline 0.8 & 4 & \pm 20 & Gaussian \\
\hline
\end{tabular}

Registered results were transferred to the roughness tester software where profile and roughness curves and also other roughness parameters are developed (see Figs. 2 and 3).

The performed processing experiments $(\mathrm{E} 1 \div \mathrm{E} 13)$ revealed that the Ra maximum values belong to the following interval: $\operatorname{Ra} C[0.738 ; 1.206] \mu \mathrm{m}$.

The cutting parameters used during processing and the values of the measured $\mathrm{Ra}$ roughness parameter associated with the experimental cases are shown in Table 5. 


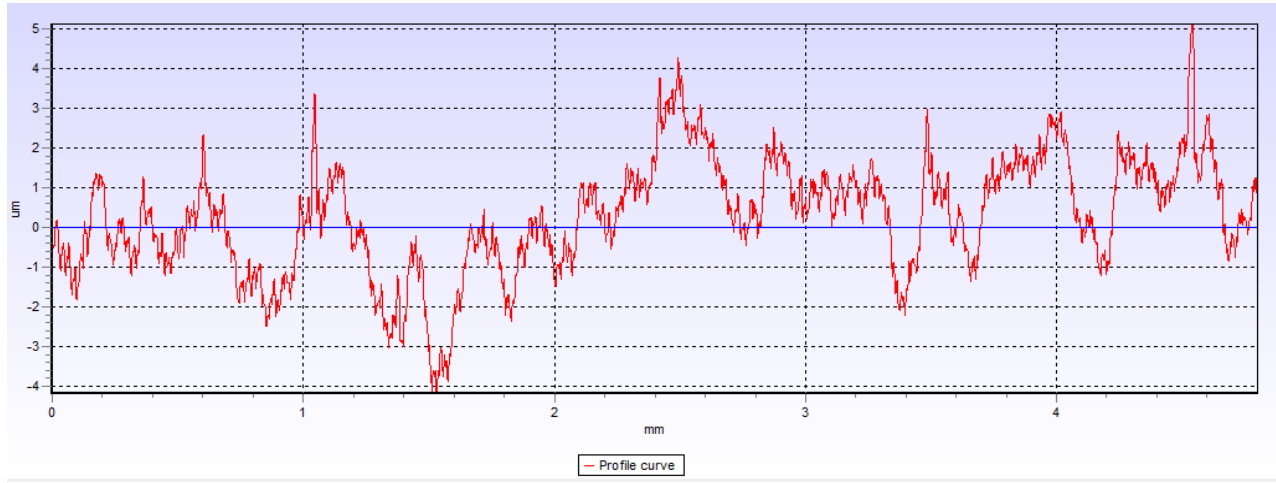

Fig. 2. Profile curve for E13 experimental case.

\begin{tabular}{|c|c|c|c|c|c|c|c|c|c|c|c|}
\hline $\begin{array}{c}0.738 \text { ìm } \\
\mathbf{R a}\end{array}$ & $\begin{array}{l}4.480 \text { ìm } \\
\mathbf{R z}\end{array}$ & $\begin{array}{c}5.958 \text { im } \\
\text { Rt }\end{array}$ & $\begin{array}{c}0.904 \text { ìm } \\
\mathbf{R q}\end{array}$ & $\begin{array}{c}2.410 \text { ìm } \\
\mathbf{R p}\end{array}$ & $\begin{array}{l}2.782 \\
\text { Rku }\end{array}$ & -0. & & $\begin{array}{l}0.0 \\
\mathbf{R p c}\end{array}$ & & $\begin{array}{r}7.8 \% \\
\text { Mr1 }\end{array}$ & $\begin{array}{l}87.8 \% \\
\text { Mr2 }\end{array}$ \\
\hline $\begin{array}{l}2.070 \text { ìm } \\
\mathbf{R v}\end{array}$ & $\begin{array}{l}2.124 \\
\mathbf{R 3 z}\end{array}$ & $\begin{array}{l}2.585 \\
\mathbf{R 3 y}\end{array}$ & $\begin{array}{l}2.492 \text { ìm } \\
\text { Rz(JIS) }\end{array}$ & $\begin{array}{c}0.035 \mathrm{~mm} \\
\mathbf{R s}\end{array}$ & $\begin{array}{l}0.100 \\
\text { Rsn }\end{array}$ & & & & & $\begin{array}{l}51 \mu \mathrm{m} \\
\mathbf{p k}\end{array}$ & $\begin{array}{l}0.816 \mu \mathrm{m} \\
\mathbf{R v k}\end{array}$ \\
\hline
\end{tabular}

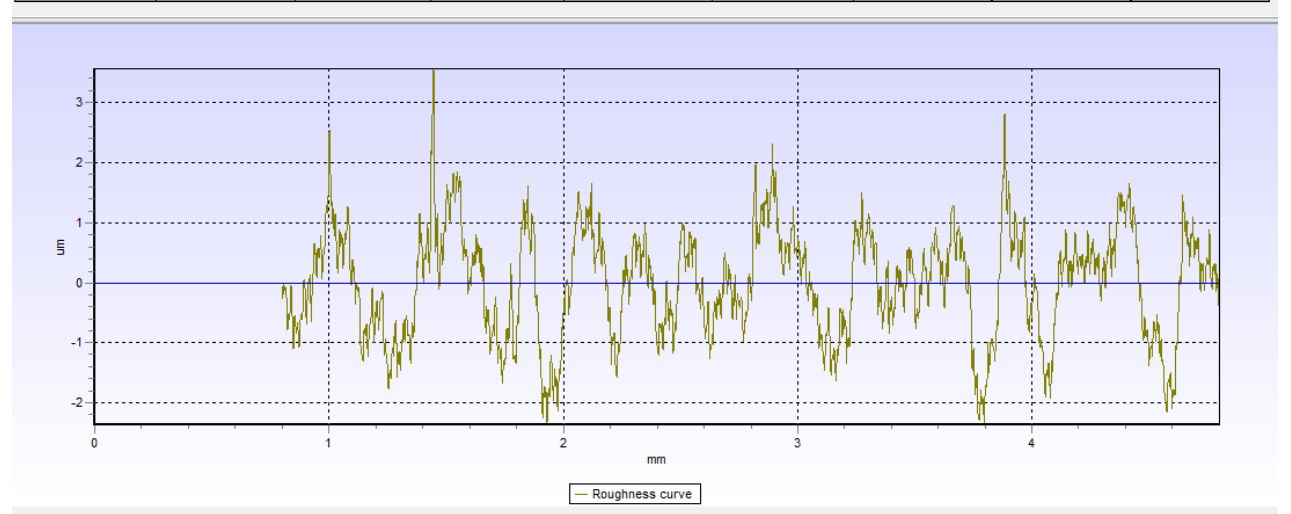

Fig. 3. Roughness parameters and roughness curve for E13 experimental case.

Table 5. Cutting data and measured Ra roughness parameter.

\begin{tabular}{|c|c|c|c|c|c|c|c|c|c|c|c|c|c|}
\hline Exp. no. & E1 & E2 & E3 & E4 & E5 & E6 & E7 & E8 & E9 & E10 & E11 & E12 & E13 \\
\hline $\begin{array}{l}\text { Depth of cut } \\
a_{p}(\mathrm{~mm})\end{array}$ & & & 0.375 & & & 0.25 & 0.3 & 0.375 & 0.4 & 0.5 & & 0.375 & \\
\hline $\begin{array}{l}\text { Feed rate } \\
\mathrm{f}(\mathrm{mm} / \mathrm{rev})\end{array}$ & 0.03 & 0.04 & 0.05 & 0.06 & 0,07 & \multicolumn{8}{|c|}{0.05} \\
\hline $\begin{array}{l}\text { Cutting speed } \\
\mathrm{v}_{\mathrm{c}},(\mathrm{m} / \mathrm{min})\end{array}$ & \multicolumn{10}{|c|}{25} & 20 & 25 & 32 \\
\hline Ra parameter $(\mu \mathrm{m})$ & $\stackrel{\infty}{\stackrel{\infty}{\imath}}$ & $\frac{m}{\sigma}$ & ริ & $\stackrel{n}{\sigma}$ & ঙั & $\frac{n}{a}$ & ڤે & İ & $\hat{n}$ & 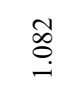 & $\stackrel{\infty}{=}$ & ริ & $\stackrel{\infty}{\stackrel{\infty}{0}}$ \\
\hline
\end{tabular}

\section{Results processing}

The variation of the Ra roughness parameter in relation to the cutting regime parameters considered for the experimental research - feed rate, $f$, depth of cut, $a_{p}$, and cutting speed, $\mathrm{v}_{\mathrm{c}},-$ is shown in figures 4-6. 


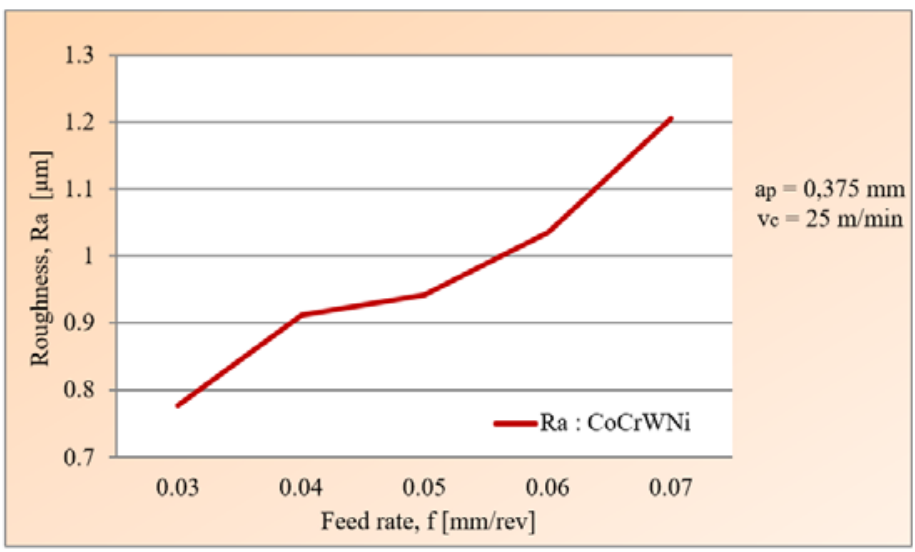

Fig. 4. Variation of surface roughness, $\mathrm{Ra}$, in relation to the feed rate, $\mathrm{f}$.

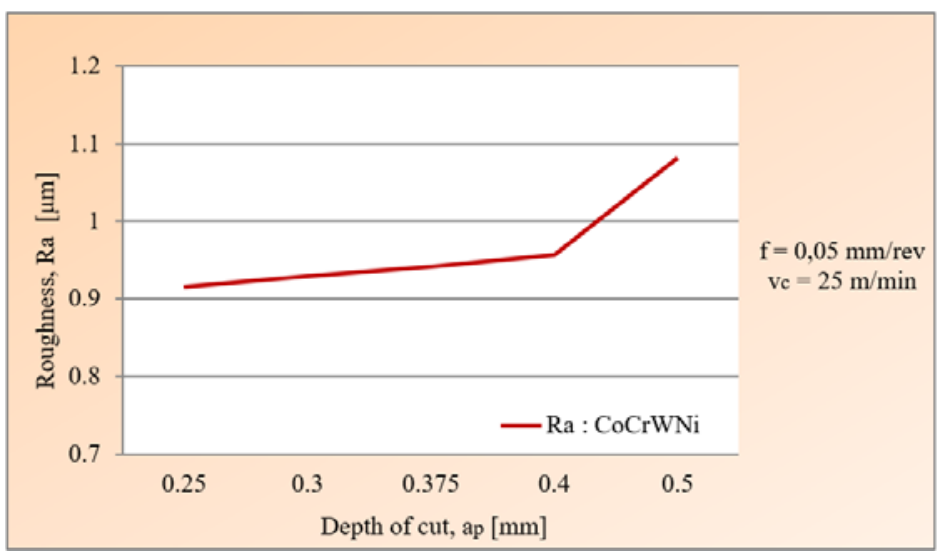

Fig. 5. Variation of surface roughness, Ra, in relation to the depth of cut, ap.

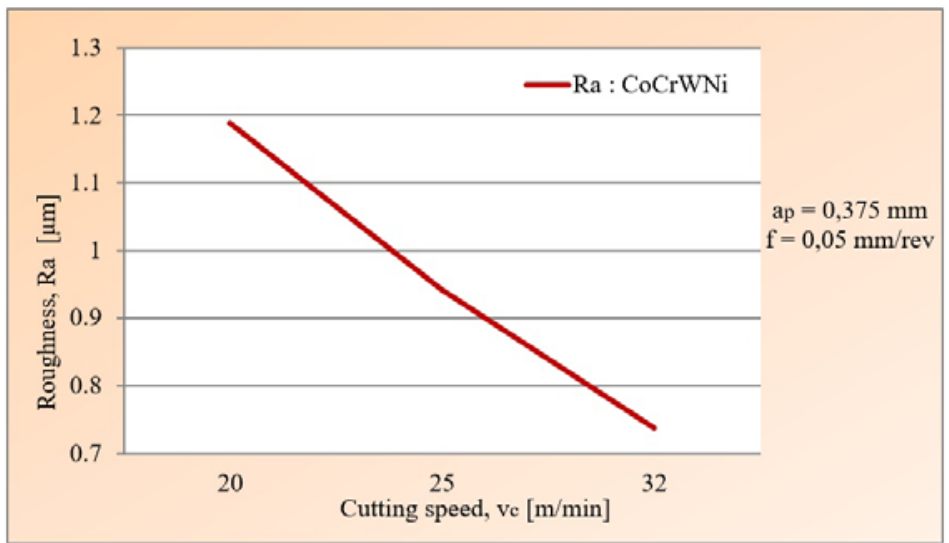

Fig. 6. Variation of surface roughness, Ra, in relation to the cutting speed, $\mathrm{v}_{\mathrm{c}}$.

After the analysis of the Ra variation graphs, it can be determined that the influence of each cutting parameter on the Ra roughness parameter value, when the other parameters are constant, is: the surface roughness increases by $55.01 \%$ when the feed increases by $133.3 \%$; the surface roughness increases by $18.25 \%$ when the depth of cut increases by $100 \%$; the surface roughness decreases by $38.89 \%$ when the cutting speed increases by $60 \%$. 


\section{Conclusions}

This research paper presents an experimental investigation on the influence of cutting regime parameters upon surface roughness when dry turning a CoCrWNi alloy, made in order to complete the existing studies on the machinability of this alloy.

The $\mathrm{Ra}$ roughness parameter value is increasing with the growth of the feed rate and depth of cut cutting parameters and is decreasing with the growth of the cutting speed parameter. The highest influence on surface roughness is exerted by the feed rate: $55.01 \%$ when the feed rate increases by $133.3 \%$ and $33.03 \%$ when the feed rate increases by $100 \%$. The lowest influence on surface roughness is exerted by the depth of cut: $18.25 \%$ when $\mathrm{a}_{\mathrm{p}}$ increases by $100 \%$ and the highest modification (growth of $13.6 \%$ ) occurs when $a_{p}$ grows from 0.4 to $0.5 \mathrm{~mm}$; nevertheless this parameter has a low influence on surface roughness.

Similar to other machining processes, the surface quality increases when the cutting speed increase and decreases when the feed rate and depth of cut parameters increase. The cutting parameters taken into account for this experimental research have a nonlinear influence on the Ra surface roughness parameter.

Further research will consist in the development of a roughness parameter ( $\mathrm{Ra})$ prediction model for dry longitudinal turning of the analysed alloy, a model which can be used in the industrial area for establishing the necessary cutting data in order to obtain a certain surface quality.

This work has been funded by University POLITEHNICA of Bucharest, through the "Excellence Research Grants" Program, UPB - GEX 2017. Identifier: UPB-GEX 2017, "Machinability analysis of some metallic biomaterials", ctr. no. 51/25.09.2017.

\section{References}

1. J. Park, R.S. Lakes, Biomaterials - An introduction (Springer-Verlag, New York, 2007)

2. G. Heness, B. Ben-Nissan, Materials Forum 27, 104-114 (2004)

3. M.J. Jackson, T. Novakov, M.B. da Silva, Machining with Nanomaterials, 231-271, (Springer International Publishing, Switzerland, 2015)

4. A. M. Khorasani, I.Gibson, M. Goldberg, J. Nomani, G. Littlefair, Sci. of Adv. Mat. 8, 1491-1511 (2016)

5. A.B. Novaes, S.L.S. Souza, R.R.M. Barros, K.K.Y. Pereira, G. Iezzi, A. Piattelli, Braz. Dent. J. 21(6), 471-481, (2010)

6. G. Yingfei, P. Munoz de Escalona, A. Galloway, J. of Materi. Eng. and Perform. 26, 312-326 (2017)

7. M. Gheorghe, M.R. Dijmărescu, G.E. Armășoiu, Laboratory support-guidebook at Engineering and Management of Production Processes (Politehnica Press, 2016)

8. H. A. Zamana, S. Sharifb, D-W. Kim, M.H. Idris, M.A. Suhaimi, Z. Tumurkhuyag, Procedia Manufacturing 11, 563-570 (2017)

9. ISO 5832-5:2005, Implants for surgery -- Metallic materials -- Part 5: Wrought cobalt-chromium-tungsten-nickel alloy

10. http://www.iscar.com/eCatalog/Item.aspx?cat=3603117, accessed on 10.02.2018

11. http://www.iscar.com/eCatalog/Item.aspx?cat $=5567594$, accessed on 10.02 .2018 